\title{
Memahami Hak Untuk Hidup Dalam Islam Berdasarkan Deklarasi Kairo
}

\author{
Endrika Widdia Putri \\ UIN Sunan Kalijaga Yogyakarta \\ endrikawiddiaputri@yahoo.co.id
}

\begin{abstract}
Humanizing human beings is a part of respecting one's own right to life. Because humans are one with another human being like one body. Humans cannot be called humans if there is no respect for other humans. In this case, the right to life is the most important right in Islam. This is regulated in the Cairo Declaration (1990) on which the basis is the a-Qur'an, which is contained in chapters 2 verses 1-4 and in this paper analyzed verses $1-2$. Understanding the right to live in the Cairo Declaration is expected to be able to present values and meanings in the lives of every human person that life must be maintained at the same time glorified. Article 2 verses 1-2 explain that killing one human soul is the same as killing all human souls let alone mass murder of humans. The prohibition of killing is not only able to damage the order of society, race, ethnicity and others. But also damage the pride of a nation and even all people who live on earth. As for theologically, the perpetrators of killings have indirectly committed crimes against God as the Creator of humans.
\end{abstract}

Keywords: right to life, cairo declaration, humanizing humans

\begin{abstract}
Abstrak
Memanusiakan manusia adalah bagian dari menghargai hak hidup diri sendiri. Sebab manusia satu dengan manusia yang lain tak ubahnya satu tubuh. Manusia tidak dapat disebut sebagai manusia jika tidak ada respect terhadap manusia lain. Dalam hal ini, hak untuk hidup menjadi hak yang paling utama dalam Islam. Hal ini salah satu diatur dalam Deklarasi Kairo (1990) yang landasannya adalah $a$ Qur'ān, yang terdapat dalam pasal 2 ayat $1-4$ dan pada tulisan ini dianalisis ayat 1-2. Memahami hak untuk hidup dalam Deklarasi Kairo diharapkan mampu menghadirkan nilai dan makna dalam kehidupan setiap pribadi manusia bahwa hidup harus dipertahankan sekaligus dimuliakan. Pasal 2 ayat 1-2 menjelaskan bahwa membunuh satu jiwa manusia sama dengan membunuh seluruh jiwa manusia apalagi melakukan pembunuhan massal kepada manusia. Pelarangan pembunuhan ini bukan hanya dapat merusak tatanan masyarakat, ras, suku dan lain-lainnya. Melainkan juga merusak harga diri suatu bangsa dan bahkan seluruh manusia yang hidup di muka bumi. Adapun secara teologis, pelaku pembunuhan
\end{abstract}


secara tidak langsung telah melakukan kejahatan terhadap Tuhan sebagai Pencipta manusia.

Kata Kunci: hak untuk hidup, deklarasi kairo, memanusiakan manusia

\section{A. Pendahuluan}

Setiap orang tahu, bahkan harus tahu, mengapa hak-hak asasi manusia itu penting. Hak-hak asasi manusia penting karena tanpa hak itu tidak akan ada hak martabat manusia. Banyak orang berpendapat bahwa hidup tanpa hak adalah kehidupan tidak bermartabat. ${ }^{1}$ Ini artinya memiliki sikap respect terhadap hidup diri sendiri dan orang lain adalah tanda bahwa manusia itu bermartabat. Sebaliknya, jika ia tidak respect terhadap hidup diri sendiri dan orang lain itu berarti tanda ia tak bermartabat.

Potret Hak Asasi Manusia (HAM) adalah mozaik sejarah tentang penegakan kemerdekaan, kebebasan, keadilan, persamaan, perdamaian, persaudaraan, dan perlindungan. ${ }^{2}$ Setiap manusia berhak mendapatkannya, kuantitas dan kualitasnya setara, tidak ada yang membedakannya. Entah itu suku, etnis, budaya, agama, ras dan lain sebagainya semuanya sama di mata hukum.

Deklarasi Kairo tentang HAM dalam Islam adalah deklarasi HAM yang diadakan di Kairo, Ibukota Mesir pada 1990 oleh Organisasi Konferensi Islam (OKI) dan diakui oleh Perserikatan Bangsa-Bangsa (PBB). ${ }^{3}$ Satu dari 25 pasal Deklarasi Kairo adalah hak untuk hidup yang terdapat pada pasal 2 ayat $1-4 .^{4}$ Hak untuk hidup dan menghargai hak hidup semua manusia adalah hak yang pertama kali dianugerahkan Islam di antara HAM lainnya. ${ }^{5}$

${ }^{1}$ Peter Davies, Hak-hak Asasi Manusia: Sebuah Bunga Rampai, terj. A. Rahman Zainuddin, (Jakarta: Yayasan Obor Indonesia, 1994), hlm. 46.

${ }^{2}$ Mohammad Luqman Hakiem, Deklarasi Islam tentang HAM, (Surabaya: Risalah Gusti, 1992), hlm. 1.

${ }^{3}$ Dalam https://id.wikipedia.org/wiki/Deklarasi_Kairo_tentang_Hak_Asasi_Manusia _dalam_Islam, diakses pada hari Minggu, 19 Mei 2019, jam 09.44 WIB.

${ }^{4}$ Matinus Sadri, "Mengenal Hak Asasi Manusia dalam Islam Berdasarkan Deklarasi Kairo", Makalah, hlm. 7-8, dalam https://repository.umy.ac.id, diakses pada hari Minggu, 19 Mei 2019, jam 09.47 WIB.

${ }^{5}$ Syekh Syaukat Hussain, Hak-hak Manusia dalam Islam, terj. Abdul Rochim, (Jakarta: Gema Insani Press, 1996), hlm. 60. 
Islam menganugerahkan hak untuk hidup sebagai hak yang pertama kali dianugerahkan dikarenakan Islam sangat menjunjung tinggi harkat dan martabat manusia. Al-Qur'an sebagai sumber Islam menganggap bahwa pembunuhan terhadap seseorang manusia adalah sama dengan pembunuhan terhadap seluruh umat manusia (Q.S. al-Ma'idah [5]: 32). ${ }^{6}$ Merujuk kepada Deklarasi Kairo yang memuat pasal tentang hak untuk hidup maka penting bagi semua manusia tanpa terkecuali menjunjung hak untuk hidup dirinya dan orang lain. Hidup bermanfaat, berkarya, dan produktif merupakan bagian dari menjunjung hak untuk hidup. Sementara, hidup merusak, makar, dan statis merupakan bagian dari tidak menjunjung hak untuk hidup.

Manusia satu dengan manusia lainnya memiliki tanggung jawab untuk saling mengingatkan dan menyemangati akan hak untuk hidup semua manusia. Oleh karena itu, penting untuk diketahui bagaimana memahami hak untuk hidup dalam Islam berdasarkan Deklarasi Kairo. Dengan memahami hak untuk hidup tersebut diharapkan mampu menghadirkan nilai dan makna dalam kehidupan setiap pribadi manusia bahwa hidup harus dipertahankan.

\section{B. Hak Asasi Manusia dalam Deklarasi Kairo}

Hak Asasi Manusia dalam Islam merupakan keharusan untuk dikenal di Indonesia, karena mayoritas penduduk Indonesia beragama Islam. Semua manusia mempunyai tugas untuk semakin mendalami HAM dalam Islam ini, mensosialisasikannya, mempromosikannya, dan mengimplementasikannya dalam kehidupan bermasyarakat secara nyata. ${ }^{7}$ Sehingga ia tidak hanya menjadi secercik kertas atau dokumen biasa namun bermakna dan bernilai.

Deklarasi Kairo Hak Asasi Manusia dalam Islam merupakan gambaran umum mengenai HAM berdasarkan perspektif Islam dan menegaskan Islam

\footnotetext{
${ }^{6}$ Syekh Syaukat Hussain, Hak-hak Manusia dalam Islam ..., hlm. 60.

${ }^{7}$ Matinus Sadri, "Mengenal Hak Asasi Manusia dalam Islam Berdasarkan Deklarasi Kairo"..., hlm. 1
} 
syariah sebagai yang satu-satunya sumber. ${ }^{8}$ Deklarasi ini merumuskan poin-poin hak asasi manusia yang terdapat sekitar 25 pasal yang sebagian besar mengutip dari Al-Qur'an, sebagai dasar acuan dan sumber ajaran nilai-nilai Islam. ${ }^{9}$

Deklarasi Kairo ini hadir bukan saja sebagai saingan atas dokumen HAM yang diproduksi oleh Perserikatan Bangsa-Bangsa (PBB) atas dasar universalitasnya, namun juga untuk mengakomodir umat Islam $^{10}$ dalam menentukan hak asasinya. Sekaligus untuk menjadi pegangan yang harus dipraktekan bagi umat Islam agar tidak terjadinya pelanggaran HAM.

Ajaran HAM dalam Islam hadir jauh sebelum diadakannya Deklarasi Umum Hak Asasi Manusia PBB tahun 1948 yang memuat 30 pasal. ${ }^{11}$ Jauh sebelum HAM PBB itu didengungkan, 14 abad silam, secara sempurna Tuhan memproklamirkan HAM Universal yang mengatur tata dunia dan peradaban manusia. HAM itu dideklarasikan lewat Rasul-Nya, Nabi Muhammad SAW. lewat ajaran-ajaran al-Qur'an dan Sunnah. ${ }^{12}$ Ini artinya Islam sangat menjunjung tinggi yang namanya HAM sejak awal peradaban Islam itu hadir.

Dalam praktek HAM apabila manusia menyadari bahwa sejak lahirnya telah diberkati hak yang paling asasi oleh Tuhan, tentu saja, manusia tidak bisa menutup mata dan telinganya untuk mendengarkan doktrin-doktrin yang diberikan Tuhan mengenai kelangsungan hak kehidupannya. ${ }^{13}$ Dalam menentukan kelangsungan hak hidupnya manusia memiliki kebebasan, yang mana kebebasan

${ }^{8}$ Yahya Ahmad Zein, "Konsep Hak Asasi Manusia dalam Islam (Mengungkapkan Korelasi antara Islam dengan HAM)", Makalah, hlm. 106, dalam https://journal.unpar.ac.id, diakses pada hari Minggu, 19 Mei 2019, jam 10.04 WIB.

${ }^{9}$ Dalam https://id.wikipedia.org/wiki/Deklarasi_Kairo_tentang_Hak_Asasi_Manusia _dalam_Islam, diakses pada hari Minggu, 19 Mei 2019, jam 10.05 WIB.

${ }^{10}$ Agus Dedi Putrawan, "Membumikan Deklarasi Kairo di Indonesia: Perlindungan terhadap Hak Anak dan Keluarga", Tasamuh, Vol. 14, No. 2, Juni 2016, hlm. 185, dalam https://journal.uinmataram.ac.id, diakses pada hari Minggu, 19 Mei 2019, jam 10.07 WIB.

${ }^{11}$ Izzudin Washil dan Ahmad Khoirul Fata, "HAM Islam dan DUHAM PBB:Sebuah Ikhtiar Mencari Titik Temu, Miqot, Vol. XLI, No. 2, Juli-Desember 2017, hlm. 431, dalam https://media.neliti.com, diakses pada hari Minggu, 19 Mei 2019, jam 10.09 WIB.

${ }^{12}$ Mohammad Luqman Hakiem, Deklarasi Islam tentang HAM, (Surabaya: Risalah Gusti, 1992), hlm. 9

${ }^{13}$ Mohammad Luqman Hakiem, Deklarasi Islam tentang HAM..., hlm. 9. 
ini merupakan penghormatan atas harkat dan martabat manusia sebagai individu dalam kapasitas sebagai hamba Allah dan khalifah Allah di muka bumi. ${ }^{14}$

Pemberian kebebasan terhadap individu-individu bukan berarti mereka dapat menggunakan kebebasan tersebut secara mutlak, tetapi di dalam kebebasan itu terkandung hak dan kepentingan orang lain yang harus dihormati juga. ${ }^{15}$ Artinya kebebasan yang dimiliki manusia berbarengan dengan tanggung jawab yang harus dipikulnya jika ia menghina, mencaci atau merampas hak hidup orang lain.

\section{Deklarasi Kairo Pasal 2 Ayat 1}

"Kehidupan adalah karunia Allah dan dijamin untuk setiap manusia. Tugas individu, masyarakat dan negara melindungi hak ini terhadap setiap pelanggaran, dan dilarang mengambil nyawa tanpa alasan yang ditentukan syari'at." (Deklarasi Kairo Pasal 2 ayat 1)

Agama manapun tidak ada kiranya yang menghalalkan melakukan pelanggaran terhadap nyawa seseorang. Setiap agama pasti membela harkat dan martabat serta nyawa setiap manusia, termasuk agama Islam. Dalam agama Islam kehidupan adalah karunia. Jiwa manusia sangat dihargai dan dijunjung tinggi, ia adalah makhluk mulia dan mahkluk ciptaan Allah yang paling terbaik.

Akal dan kalbu yang manusia miliki mampu menjadikan ia sosok Insan Kamil (manusia sempurna). Dengan akal dan kalbu tersebut ia memiliki kemampuan untuk dapat membedakan mana yang baik dan mana yang buruk. Ia juga memiliki kebebasan untuk memilih jalan yang benar dan lurus yang akan mengantarkan ia mencapai kedekatan hakiki dengan Tuhan Sang Pencipta alam jagad raya ini.

Semulia ini setiap jiwa manusia sehingga melakukan pembunuh terhadapnya nyawanya adalah kesalahan manusia yang lupa menggunakan akal

${ }^{14}$ Makhrur Adam Maulana, Konsepsi HAM dalam Islam: Antara Universalitas dan Partikularitas, (Yogyakarta: CV. Pustaka Ilmu Group, 2015), hlm. 26.

${ }^{15}$ Makhrur Adam Maulana, Konsepsi HAM dalam Islam: Antara Universalitas dan Partikularita..., hlm. 27. 
dan kalbunya. Dianggap sangat tidak manusiawi dan bukan tindakan yang mulia ketika manusia menghabisi nyawa sesamanya. Dalam al-Quran Surat al-Isra [17]: 33, Allah berfirman

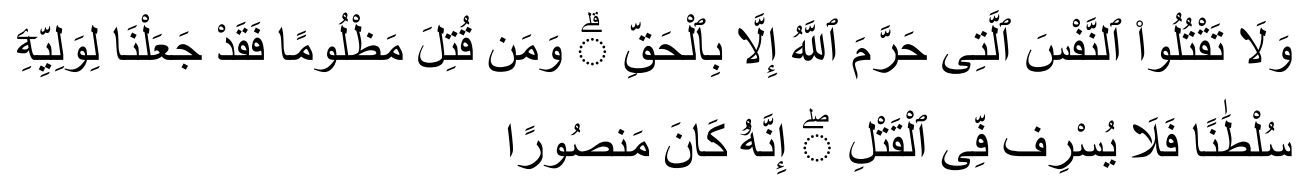

"Dan janganlah kamu membunuh jiwa yang diharamkan Allah (membunuhnya), melainkan dengan suatu (alasan) yang benar. dan Barangsiapa dibunuh secara zalim, Maka Sesungguhnya Kami telah memberi kekuasaan kepada ahli warisnya, tetapi janganlah ahli waris itu melampaui batas dalam membunuh. Sesungguhnya ia adalah orang yang mendapat pertolongan".

Quraish Shihab menafsirkan bahwa ayat ini merupakan larangan membunuh jiwa, baik jiwa orang lain maupun jiwa sendiri, kecuali dengan haq. Haq maksudnya yaitu dalam kondisi yang dibenarkan agama. ${ }^{16}$ Quraish Shihab menyebut bahwa pengecualian tersebut menurut Sayyid Quthub ada tiga hal: pertama, atas dasar qishash. Kedua, rajam karena berzina. Ketiga, murtad. ${ }^{17}$

Ayat ini juga menjelaskan tentang keadilan bagi manusia yang dibunuh secara zalim, yakni ahli warisnya dapat menuntut "qishash" atau ganti rugi kepada keluarga si pembunuh melalui hakim yang berwenang. ${ }^{18}$ Namun, dilarang melampaui batas dalam menuntut balasan, yakni menuntut membunuh apalagi melakukan pembunuhan dengan main hakim sendiri. ${ }^{19}$

Hak untuk hidup adalah hak yang tak dapat ditawar lagi (non derogable rights). ${ }^{20}$ Artinya tak ada alasan apapun untuk tidak menghargai hak hidup seseorang dan diri sendiri. Hanya seseorang yang tak menghargai hak hidupnya pula yang tak mampu menghargai hak hidup orang lain. Maka, tak menghargai hak hidup orang lain sama dengan tak menghargai hak hidup diri sendiri. Maka,

${ }^{16}$ M. Quraish Shihab, Tafsir al-Mishbah: Pesan, Kesan, dan Keserasian al-Qur'an, (Jakarta: Lentera Hati, 2002), Vol. 15, hlm. 81.

17 M. Quraish Shihab, Tafsir al-Mishbah: Pesan, Kesan, dan Keserasian alQur'an, hlm. 82.

${ }^{18}$ M. Quraish Shihab, Tafsir al-Mishbah: Pesan, Kesan, dan Keserasian al-Qur'an..., hlm. 81.

${ }^{19}$ M. Quraish Shihab, Tafsir al-Mishbah: Pesan, Kesan, dan Keserasian al-Qur'an..., hlm. 81

${ }^{20}$ Eva Achjani Zulfa, "Menelaah Arti Hak untuk Hidup sebagai Hak Asasi Manusia", Lex Jurnalica, Vol. 3 / No. 1 / April 2015, hlm. 13, dalam https://media.neliti.com, diakses pada hari Minggu, 19 Mei 2019, jam 10.16 WIB. 
penting untuk menghargai hak hidup diri sendiri yang akan melahirkan rasa untuk menghargai hak hidup orang lain.

Merujuk pada hakekat hak asasi manusia itu sendiri yang inherent pada dan tak dapat dipisahkan lagi dari sifat kodrati manusia sebagai kehendak Tuhan sekalian alam, dan karenanya setiap manusia berhak atas hidup, atas kebebasan dan keselamatan pribadinya. ${ }^{21}$ Ini artinya Tuhan memberikan hak prerogratif bagi setiap manusia untuk saling harga menghargai akan hak hidup masing-masing.

Jika tidak ada hak untuk hidup maka tidak akan ada pokok persoalan dalam hak asasi manusia. Hal ini dikarenakan hak untuk hidup merupakan hak yang memiliki nilai paling mendasar dari peradaban manusia. ${ }^{22}$ Adanya HAM merupakan kesepakatan umat manusia untuk saling menjunjung tinggi hak masing-masing demi terciptanya peradaban yang humanis dalam sejarah perkembangan hidup manusia. Semakin baik pengendalian HAM terutama hak untuk hidup maka semakin baik pula tatanan suatu Negara.

Perjuangan menegakkan hak asasi manusia pada hakikatnya merupakan bagian dari tuntutan sejarah dan budaya dunia, termasuk Indonesia. Karena itu, memperjuangkan HAM sama dengan memperjuangkan budaya bangsa atau "membudayakan" bangsa, antara manusia dan kemanusiaan seluruh dunia sama dan satu. ${ }^{23}$ Maka, indahnya sejarah dan budaya suatu Negara dapat ditentukan dari sejauh mana manusia yang ada di Negara tersebut hidup aman, damai, dan tenang. Untuk mencapai semua itu perlu membumikan budaya respect terhadap sesama warga Negara dan segala yang ada di dalam Negara.

Membumikan budaya respect, cinta sesama, dan kesetaraan manusia akan menimbulkan rasa untuk saling harga menghargai, dan menganggap sama pentingnya diri sendiri maupun orang lain. Tuhan tak pernah membeda-bedakan

\footnotetext{
${ }^{21}$ Ismail Suny, "Hak Asasi Manusia di Indonesia”, Hukum dan Pembangunan, Juni 1992, hlm. 241, dalam https://jhp.ui.ac, diakses pada hari Minggu, 19 Mei 2019, jam 10.20 WIB. 13.

${ }^{22}$ Eva Achjani Zulfa, "Menelaah Arti Hak untuk Hidup sebagai Hak Asasi Manusia”..., hlm.

${ }^{23}$ A. Masyhur Effendi, dan Taufani S. Evandri, HAM dalam Dimensi/Dinamika Yuridis, Sosial, Politik: dan Proses Penyusunan/Aplikasi Ha-Kham (Hukum Hak Asasi Dalam Masyarakat, (Bogor: Penerbit Ghalia Indonesia, 2010), hlm. 135.
} 
mahkluknya yang membedakannya hanyalah tingkatan takwanya. Sebagai mahkluk perlu untuk menyadari hal yang tersebut di atas, bahwasanya manusia entah derajat dan kedudukannya tinggi, ia orang kaya, penguasa, pemimpin, dan lain-lain sebagainya tidak ada bedanya kemuliaannya sebagai mahkluk dengan orang-orang yang miskin, lemah dan lain-lain sebagainya.

\section{Deklarasi Kairo Pasal 2 Ayat 2}

"Dilarang menggunakan cara apapun yang dapat mengakibatkan genosida umat manusia”. (Deklarasi Kairo Pasal 2 Ayat 2)

Islam menganugerahkan hak hidup ini kepada setiap manusia dari ras, bangsa, maupun agama ia berasal. Rasullullah SAW. bersabda: "Seseorang yang membunuh orang yang di bawah perjanjian (seorang warga Negara nonmuslim dalam Negara Islam) tidak akan merasakan surga walau hanya mencium wanginya". (H.R. Bukhari)

Dari hadits Rasulullah di atas dapat dipahami bahwa Rasul sangat membenci yang namanya pembunuhan. Dalam hal ini, pembunuhan terhadap nonmuslim yang hidup di bawah Negara yang sama dengan muslim yang ia juga memiliki hak yang sama di mata hukum. Rasulullah bahkan mengatakan tidak akan mencium wanginya surga bagi yang melakukan pembunuhan terhadap nonmuslim (kafir harbi). Dari hadits ini, dapat ditarik pula suatu kesimpulan bahwasanya apapun agama seseorang entah muslim nonmuslim semuanya memiliki hak untuk hidup. Hidup bukan tentang muslim atau nonmuslim namun tentang jiwa manusia yang mulia serta dijunjung tinggi. Maka, apapun agama manusia, manusia tersebut berhak untuk hidup dan saling menjaga kehidupan.

Al-Qur'an sendiri sebagai sumber ajaran Islam menyebutkan bahwa membunuh jiwa seseorang sama dengan membunuh seluruh umat manusia. Allah berfirman: 


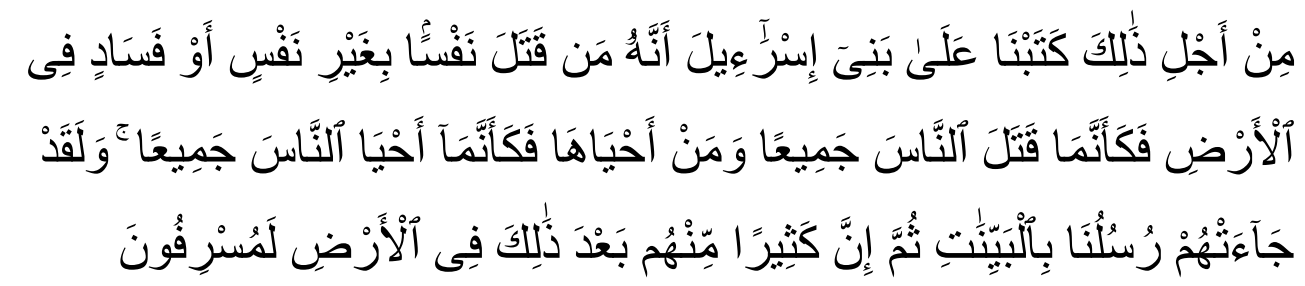

"Oleh karena itu Kami tetapkan (suatu hukum) bagi Bani Israil, bahwa: Barangsiapa yang membunuh seorang manusia, bukan karena orang itu (membunuh) orang lain, atau bukan karena membuat kerusakan dimuka bumi, Maka seakan-akan Dia telah membunuh manusia seluruhnya. dan Barangsiapa yang memelihara kehidupan seorang manusia, Maka seolah-olah Dia telah memelihara kehidupan manusia semuanya. dan Sesungguhnya telah datang kepada mereka Rasul-rasul Kami dengan (membawa) keterangan-keterangan yang jelas, kemudian banyak diantara mereka sesudah itu sungguh-sungguh melampaui batas dalam berbuat kerusakan dimuka bumi." (Q.S. al-Ma'idah [5]: 32)

Dalam tafsir ath-Thabari dijelaskan bahwasanya membunuh seorang mukmin bukan karena alasan qishash, kafir setelah beriman, dan berzina setelah berkeluarga. Selain ketiga sebab itu, maka dilarang membunuh jiwa manusia. ${ }^{24}$ Memelihara kehidupan seseorang dengan cara memberi maaf adalah perbuatan yang disukai Allah dan perbuatan yang menandai respectnya manusia terhadap manusia lainnya.

Membunuh satu nyawa sama dengan membunuh seluruh nyawa manusia maksudnya adalah perbuatan tersebut merupakan dosa besar, sebesar ia membunuh semua orang, yang ia akan di panggang di neraka jahannam. ${ }^{25}$ Membunuh satu nyawa orang saja sama dengan membunuh seluruh umat manusia apalagi membunuh sekumpulan manusia, itu sama saja ia melawan Allah sebagai pencipta manusia. Allah berfirman:

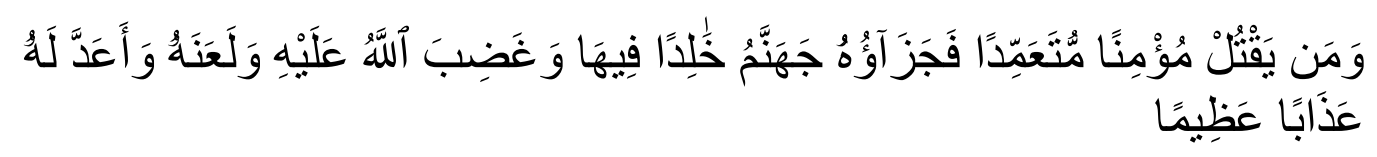

\footnotetext{
${ }^{24} \mathrm{Abu}$ Ja'far Muhammad bin Jarir ath-Thabari, Tafsir ath-Thabari, terj. Akhmad Affandi, (Jakarta: Pustaka Azzam, 2008), hlm.779

${ }^{25}$ Abu Ja'far Muhammad bin Jarir ath-Thabari, Tafsir ath-Thabari..., hlm. 780
} 
"Dan Barangsiapa yang membunuh seorang mukmin dengan sengaja Maka balasannya ialah Jahannam, kekal ia di dalamnya dan Allah murka kepadanya, dan mengutukinya serta menyediakan azab yang besar baginya." (an-Nisaa' [4]: 93)

Memelihara satu nyawa manusia sama dengan memelihara seluruh nyawa manusia maksudnya yaitu manusia yang dipelihara nyawanya tersebut memiliki potensi untuk menyelamatkan atau memelihara kehidupan manusia lainnya. Pahala dari menyelamatkan satu nyawa manusia sama dengan pahala menyelamatkan seluruh umat manusia, yang artinya pahalanya sangat besar. Memelihara nyawa orang lain juga sama dengan memelihara nyawa sendiri dan memelihara seluruh kehidupan. ${ }^{26}$

Istilah genosida terdiri dari dua kata, yakni geno dan cide. Geno atau genos berasal dari bahasa Yunani kuno yang berarti ras, bangsa atau etnis. Sedangkan cide, caedere, atau cidium berasal dari bahasa Latin yang berarti membunuh. ${ }^{27}$ Jadi, secara bahasa genosida artinya pembunuhan ras. Adapun secara istilah genosida yaitu pemusnahan seluruh kelompok manusia yang memiliki ciri umum etnis, rasial, atau agama. ${ }^{28}$

Fenomena genosida merupakan kejahatan yang paling jahat -termasuk pelanggaran yang paling keji terhadap hak hidup manusia. ${ }^{29}$ Ciri khas genosida abad ke-20 menurut Toynbee yaitu para komplotan pelakunya menggunakan segala sumber daya teknologi dan organisasi modern untuk menjadikan pembunuhan massal yang mereka rencanakan berjalan sistematis dan sempurna". 30

Di antara kasus-kasus genosida yaitu pertama, Genosida Nanking, China 40.000-300.000 warga sipil China dibunuh dan dilucuti oleh Tentara Kekaisaran Jepang. Kedua, Holocaust Nazi Jerman yang di pimpin oleh Adof Hitler, Israel

\footnotetext{
${ }^{26} \mathrm{Abu}$ Ja'far Muhammad bin Jarir ath-Thabari, Tafsir ath-Thabari..., hlm. 780

${ }^{27}$ Eddy O.S. Hiariej, Pengadilan atas Beberapa Kejahatan Serius terhadap Hak Asasi manusia, (Jakarta: Penerbit Erlangga, 2010), hlm. 7

${ }^{28}$ Antonio Cassese, Hak-hak Asasi Manusia di Dunia yang Berubah, terj. A. Rahman, (Jakarta: Yayasan Obor Indonesia, 1993), hlm. 99

${ }^{29}$ Peter Davies, Hak-hak Asasi Manusia, terj. A. Rahman Zainuddin, (Jakarta: Yayasan Obor Indonesia, 1994), hlm. 77.

${ }^{30}$ Peter Davies, Hak-hak Asasi Manusia..., hlm. 80
} 
beserta sekutunya menyebut genosida ini menewaskan 6 juta orang. Ketiga, Genosida Armenia, Pembantaian massal era Perang Dunia I dan deportasi hingga 1,5 juta orang Armenia oleh Turki Ottoman adalah masalah yang sangat sensitif baik di Armenia maupun Turki. ${ }^{31}$

Data yang ditampilkan di atas hanyalah sebagian kecil dari sejarah terjadinya fenomena genosida. Terjadinya pembunuhan massal ini tentunya merupakan hal yang sangat memilukan dan miris. Siapapun para pelaku kejahatan tersebut merupakan musuh semua umat manusia (hostishumanis generis) dan setiap negara memiliki kewajiban untuk melakukan penuntutan terhadap para pelakunya (obligatio erga omnes). ${ }^{32}$ Praktik dalam pengadilan pidana internasional telah menunjukan bagaimana para pelaku tidak bisa leluasa lepas dari penghukuman, meski posisi mereka adalah pejabat Negara. ${ }^{33}$ Siapapun pelaku genosida tanpa pandang bulu ia akan mendapatkan hukuman atas kekejian yang ia lakukan. Para pelaku kejahatan-kejahatan serius harus dibawa ke pengadilan, diadili dan dihukum. Komunitas internasional juga telah sepakat bahwa tidak ada tempat aman (no save haven) bagi para pelaku kejahatan ini. ${ }^{34}$

\section{E. Kesimpulan}

Memahami hak untuk hidup dalam Islam berdasarkan Deklarasi Kairo menjadikan manusia sadar akan pentingnya respect terhadap hidup dan kehidupan. Siapapun manusianya entah berasal dari ras, suku, budaya, adat, dan agama apapun, pantas dan layak untuk dijunjung tinggi harkat dan martabatnya. Bukan manusia namanya jika tega menghabisi satu nyawa manusia lainnya. Menghabisi nyawa manusia sama dengan menghabisi nyawa sendiri, akan ada

\footnotetext{
${ }^{31}$ Dalam https://international.sindonews.com/read/1380455/45/kasus-kasus-genosi da- terbesaryang-tercatat-dalam-sejarah-1550656869, diaks

${ }^{32}$ Zainal Abidin, dan Supriyadi Widodo Eddyono, Degradasi Extraordinary Crimes Problematika Perumusan Kejahatan Genosida, dan Kejahatan Terhadap Kemanusiaan dalam RKUHP, (Jakarta: Institute for Criminal Justice Reform , 2017), hlm. 1-2

${ }^{33}$ Zainal Abidin, dan Supriyadi Widodo Eddyono, Degradasi Extraordinary Crimes Problematika Perumusan Kejahatan Genosida, dan Kejahatan Terhadap Kemanusiaan dalam RKUHP..., hlm. 2.

${ }^{34}$ Zainal Abidin, dan Supriyadi Widodo Eddyono, Degradasi Extraordinary Crimes Problematika Perumusan Kejahatan Genosida, dan Kejahatan Terhadap Kemanusiaan dalam RKUHP..., hlm. 2.
} 
hukuman setimpal yang akan didapatkan. Memperlakukan manusia layaknya manusia kewajiban yang harus dilakukan dan merupakan proses untuk melahirkan peradaban yang matang dan humanis, sehingga tercipta ketenangan dan kebahagiaan di alam jagad raya ini.

Membunuh satu jiwa manusia sama dengan membunuh seluruh jiwa manusia. Maksudnya terdapat dosa yang luar biasa besarnya saat manusia melenyapkan nyawa manusia yang lainnya. Apalagi melakukan pembunuhan terhadap satu ras manusia, betapa besarnya dosa yang didapatkan. Kejahatan genosida tidak hanya merusak tatanan masyarakat, ras, suku dan lain-lainnya. Melainkan merusak harga diri suatu bangsa dan bahkan seluruh manusia yang hidup di muka bumi. Pelaku kejahatan tersebut tentunya adalah musuh seluruh manusia. Secara teologis, pelaku tersebut telah melakukan kejahatan terhadap Tuhan sebagai pencipta manusia.

\section{DAFTAR PUSTAKA}

Abidin, Zainal. Dan Supriyadi Widodo Eddyono. 2017. Degradasi Extraordinary Crimes Problematika Perumusan Kejahatan Genosida, dan Kejahatan Terhadap Kemanusiaan dalam RKUHP. Jakarta: Institute for Criminal Justice Reform.

Ath-Thabari, Abu Ja'far Muhammad bin Jarir. 2008. Tafsir ath-Thabari, terj. Akhmad Affandi. Jakarta: Pustaka Azzam.

Cassese,Antonio 1993. Hak-hak Asasi Manusia di Dunia yang Berubah, terj. A. Rahman. Jakarta: Yayasan Obor Indonesia.

Davies, Peter. 1994. Hak-hak Asasi Manusia: Sebuah Bunga Rampai. Terj. A. Rahman Zainuddin. Jakarta: Yayasan Obor Indonesia.

Effendi, A. Masyhur. Dan Taufani S. Evandri. 2010. HAM dalam Dimensi/Dinamika Yuridis, Sosial, Politik: dan Proses Penyusunan/Aplikasi Ha-Kham (Hukum Hak Asasi Dalam Masyarakat. Bogor: Penerbit Ghalia Indonesia.

Hakiem, Mohammad Luqman. 1992. Deklarasi Islam tentang HAM. Surabaya: Risalah Gusti.

Hiariej, Eddy O.S. 2010. Pengadilan atas Beberapa Kejahatan Serius terhadap Hak Asasi manusia. Jakarta: Penerbit Erlangga.

https://international.sindonews.com/read/1380455/45/kasus-kasus-genosidaterbesar-yang-tercatat-dalam-sejarah-1550656869. 
https://id.wikipedia.org/wiki/Deklarasi_Kairo_tentang_Hak_Asasi_Manusia_dala $\mathrm{m}$ islam,

Hussain, Syekh Syaukat. 1996. Hak-hak Manusia dalam Islam. Terj. Abdul Rochim. Jakarta: Gema Insani Press.

Maulana, Makhrur Adam. 2015. Konsepsi HAM dalam Islam: Antara Universalitas dan Partikularitas. Yogyakarta: CV. Pustaka Ilmu Group.

Putrawan, Agus Dedi. 2016. "Membumikan Deklarasi Kairo di Indonesia: Perlindungan terhadap Hak Anak dan Keluarga". Tasamuh. Vol. 14. No. 2. Juni. Dalam https://journal.uinmataram.ac.id.

Sadri, Matinus. "Mengenal Hak Asasi Manusia dalam Islam Berdasarkan Deklarasi Kairo". Makalah. Dalam https://repository.umy.ac.id.

Shihab, M. Quraish. 2002. Tafsir al-Mishbah: Pesan, Kesan, dan Keserasian alQur'an. Jakarta: Lentera Hati. Vol. 15.

Suny, Ismail. "Hak Asasi Manusia di Indonesia". Hukum dan Pembangunan, Juni 1992. Dalam https://jhp.ui.ac.

Washil, Izzudin dan Ahmad Khoirul Fata. "HAM Islam dan DUHAM PBB:Sebuah Ikhtiar Mencari Titik Temu". Miqot. Vol. XLI. No. 2. JuliDesember. Dalam https://media.neliti.com.

Zein, Yahya Ahmad. "Konsep Hak Asasi Manusia dalam Islam (Mengungkapkan Korelasi antara Islam dengan HAM)". Makalah. Dalam https://journal.unpar.ac.id.

Zulfa, Eva Achjani. 2015. "Menelaah Arti Hak untuk Hidup sebagai Hak Asasi Manusia". Lex Jurnalica, Vol. 3 / No. 1 / April. Dalam https://media.neliti.com. 